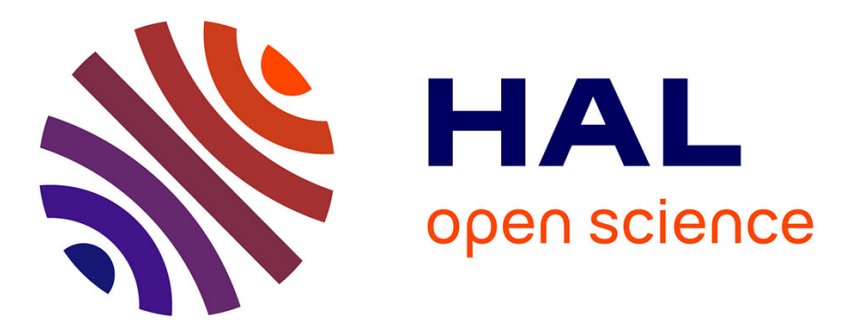

\title{
Southern Ocean laminated diatom ooze: mat deposits and potential for palaeo-flux studies, ODP leg 177, Site 1093
}

\author{
Ivo Grigorov, Richard B. Pearce, Alan E. S. Kemp
}

\section{- To cite this version:}

Ivo Grigorov, Richard B. Pearce, Alan E. S. Kemp. Southern Ocean laminated diatom ooze: mat deposits and potential for palaeo-flux studies, ODP leg 177, Site 1093. Deep Sea Research Part II: Topical Studies in Oceanography, 2002, 49 (16), pp.3391-3407. 10.1016/S0967-0645(02)00089-9 . hal-00451245

\section{HAL Id: hal-00451245 \\ https://hal.univ-brest.fr/hal-00451245}

Submitted on 3 Mar 2010

HAL is a multi-disciplinary open access archive for the deposit and dissemination of scientific research documents, whether they are published or not. The documents may come from teaching and research institutions in France or abroad, or from public or private research centers.
L'archive ouverte pluridisciplinaire HAL, est destinée au dépôt et à la diffusion de documents scientifiques de niveau recherche, publiés ou non, émanant des établissements d'enseignement et de recherche français ou étrangers, des laboratoires publics ou privés. 


\title{
Southern Ocean laminated diatom ooze: mat deposits and potential for palaeo-flux studies, ODP leg 177, Site 1093
}

\author{
Ivo Grigorov*, Richard B. Pearce, Alan E.S. Kemp \\ *School of Ocean and Earth Science, National Oceanography Center Southampton, University of Southampton, \\ SO14 3ZH, UK
}

*Corresponding author: ivo grigorov@ hotmail.com, Published in Deep Sea Research II, 21 March 2002. DOI: $10.1016 / \mathrm{S} 0967-0645(02) 00089-9$

\begin{abstract}
Laminated diatom ooze samples collected during ODP Leg 177 were analysed using scanning electron microscope (SEM) and optical microscopy to test their potential as high-resolution records of Polar Front hydrography, surface production, and export. SEM analysis from two intervals, marine isotope stage (MIS) 29 and 12/11, respectively, recovered from $50^{\circ} \mathrm{S}$ in the Atlantic Ocean (ODP Site 1093, Hole A, sections 13H-4 0$18 \mathrm{~cm}$ and $23 \mathrm{H}-40-22 \mathrm{~cm}$ ), show abundant and well-preserved Thalassiothrix antarctica mats, thought to be indicative of rapid export from the surface and deposition in the sediment. A preliminary analysis of laminae succession points to a possible annual couplet/triplet succession of laminae, and suggests exceptionally high local sedimentation rates of 57 and $80 \mathrm{~cm}$ kyr- 1 for MIS 12/11 and 29, respectively. Such high accumulation rates imply that local export from the surface layer and sequestration of biogenic silica and organic matter to the sediments may have been much higher than previously suggested.
\end{abstract}

\section{Introduction}

Laminated marine sediments preserve a highresolution record of sequential flux events from surface waters and thus offer a palaeo-archive directly comparable to core-top studies and sediment trap data. The recent application of scanning electron microscope (SEM) techniques to such sediments has unlocked this palaeo-sediment trap data and is producing new insights into mechanisms of surface productivity and the resulting flux, as well as their biogeochemical significance (e.g., Grimm et al., 1997; Kemp et al., 2000).

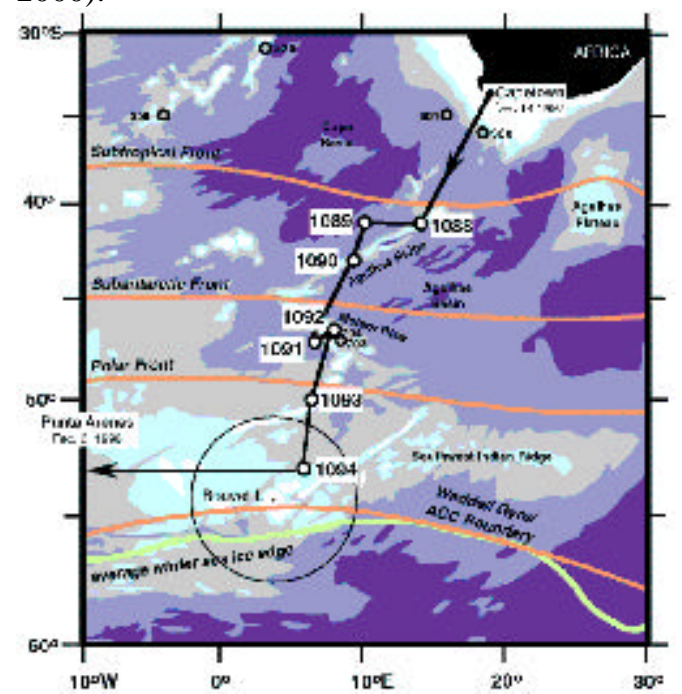

Figure 1 ODP Leg 177 site map (Shipboard Scientific Party, 1999; larger image)
The preservation of laminated marine sediments was thought to be confined to environments where anoxia had excluded bioturbating fauna, in silled marginal basins or beneath coastal upwelling cells (Bull et al., 2000; Brodie and Kemp, 1994). However, in the last decade, laminated diatom oozes have been found in deep-sea settings in the eastern equatorial Pacific Ocean (Kemp and Baldauf, 1993) and in the North Atlantic (Bod!en and Backman, 1996). Preservation of laminae in these deep-sea environments is not due to bottom water anoxia but rather to the rapid massive flux of robust diatom mats (e.g., Thalassiothrix spp.) that overwhelm and suppress benthic activity (King et al., 1995). A particular value of mat deposits is that not only laminae containing the Thalassiothrix diatom mats are preserved, but also the intercalated laminae record flux out of the surface layer between the episodes of mat sedimentation (Pearce et al., 1995), enabling a comprehensive reconstruction of the surface ocean processes that generate export production.

Southern Ocean hydrography is intimately linked to global oceanic circulation, and reconstruction of the evolution of its water masses is a vital component in understanding past climate change. Based on meridional temperature/salinity profiles, four frontal features can be identified in the Southern Ocean: the Subtropical Front (STF), the Subantarctic Front (SAF), the Polar Front (PF) and the Southern Boundary of the Antarctic Circumpolar Current (Pollard et al. (2002), and references therein). Surface waters south of the SAF are all recognised as high nutrient regions due 
to the ACC-induced divergence, yet primary productivity is generally low (El-Sayed, 1978; Sakshaug and Holm-Hansen, 1984; Nelson and Smith, 1987; Pollard et al., 2002).

Leg 177 of the Ocean Drilling Program cored a $\mathrm{N}-\mathrm{S}$ transect from $41^{\circ} \mathrm{S}$ to $53^{\circ} \mathrm{S}$ with the aim of reconstructing the palaeoceanography of the Southern Ocean over the last few million years. Three of the sites that straddle the present location of the Polar Front-1091, 1093 and 1094 contained Thalassiothrix diatom mat deposits. The most extensive development of laminated sediment occurs in Site 1093, which lies directly beneath the present Polar Front (Fig. 1). The mat deposits commonly occur between sediment characteristic of glacial periods (dark, clastic-rich with abundant
Eucampia antarctica) and pale carbonate-rich sediment characteristic of maximum interglacial or interstadial conditions (Shipboard Scientific Party, 1999). Extensive mat deposits also occur within some glacial periods such as MIS 6 (Pearce et al., in prep.). The purpose of this paper is to report an initial SEM study of these laminated diatomaceous sediments, to assess their potential for reconstruction of palaeo-flux, and to discuss implications for water-column processes.

\section{Material and methods}

2.1. Ocean Drilling Program core description and sampling

ODP Site 1093

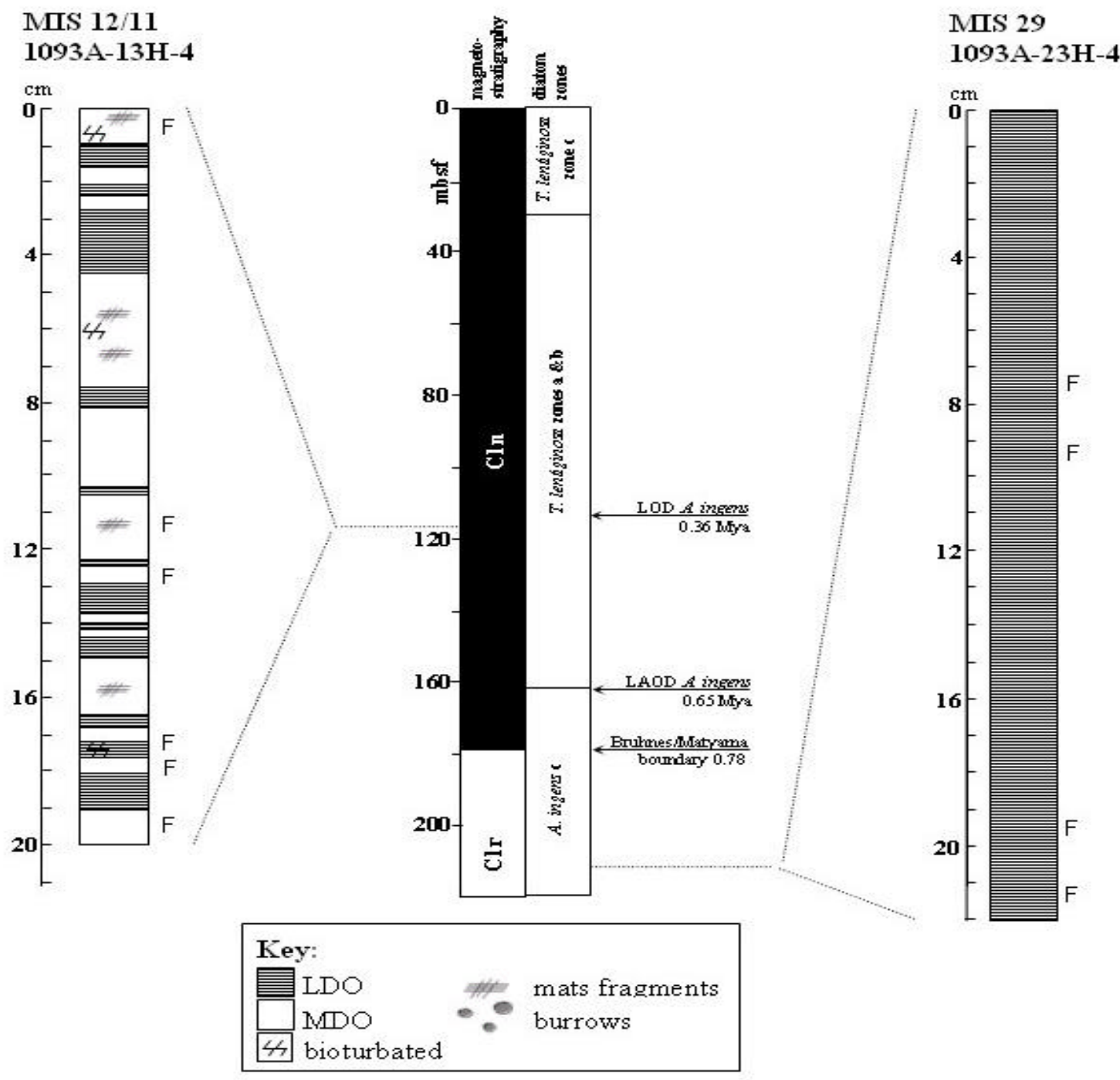

Figure 2 Sedimentological logs of the two analysed intervals: marine isotope stage 12/11 transition and marine isotope stage 29 (see text for discussion on interval dating). During MIS 29 laminated diatom ooze (LDO) is deposited continuously, while during MIS 12/11 the alternation between laminated (LDO) and massive diatom ooze (MDO) horizons persists for the entire glacial-interglacial transition. Palaeomagnetic and biostratigraphic columns are adapted from Channell and Stoner (2002) and Zielinski and Gersonde (2002), respectively. 
The sediment was collected on ODP Leg 177 undertaken in the Atlantic Sector of the Southern Ocean between December 1997 and January 1998 Fig. 1). A total of seven sites were drilled in a orthsouth transect across the main subdivisions $\mathrm{f}$ the Southern Ocean. At each site, multiple oles were cored to produce a complete composite ediment record. Visual core description in ombination with smear slide analysis (Shipboard arty, 1999) was used to identify laminated nd non-laminated intervals. A suite of samples ere taken from representative laminated zones n Site 1093, of which two intervals of approximately $0 \mathrm{~cm}$ were chosen for a detailed electron icroscope analysis (1093A-13H-4, 0-18 cm and 093A-23H-4, 0-22 $\mathrm{cm}$ ). Based on magneto-biostratigraphy (Zielinski and Gersonde, 2002; Channell \& Stoner, 2002), and the good correlation between oxygen isotopes and sediment colour reflectance data (Shipboard Scientific Party, 1999; Kanfoush and Hodell, 2002; Hodell and Venz, 1992), core section 1093A-13H$4,0-18 \mathrm{~cm}$ lies in the middle of an approximately $5 \mathrm{~m}$ of intermittently laminated interval spanning the MIS 12/11 transition and part of the MIS 11 climatic optimum (Shipboard Scientific Party, 1999). Low-magnification (x5) backscatter electron imaging (BSEI) analysis of the sediment fabric has revealed a persistent alternation of $\mathrm{cm}$-scale bundles of laminated diatom ooze (LDO) and massive diatom ooze (MDO) (Fig. 2). LDO bundles are continuously laminated, rarely contain evidence of bioturbation and have high porosity. In contrast, MDO intervals appear homogenous and brighter in BSEI, and lack laminations (i.e., denser, as deposits are predominantly composed of biogenic silica). Burrow structures are also evident.

The second selected interval, 1093A-23H-4, 0$22 \mathrm{~cm}$, is tentatively correlated using raw sediment colour reflectance (Shipboard Scientific Party, 1999), to a section at Site 1094 dated as MIS 29 (Kleiven and Jansen, 2002) and contains continuously laminated sediments (Fig. 2).

\subsection{Backscatter electron microscope analysis}

Diatom ooze samples were embedded with a Spurr low-viscosity epoxy resin following the method outlined in Pike and Kemp (1996). The procedure allows the preparation of polished thin sections cut perpendicular to bedding with minimum disturbance of the delicate sediment fabric. These sections were carbon coated and examined using a low-vacuum JEOL JSM 5300 SEM or a high-vacuum JEOL JSM 6400 SEM in backscatter electron imagery (BSEI) mode. In addition, sediment counterparts were broken along the bedding plane and the fresh surface gold coated for topographic imaging (BSEI mode) under the SEM. This allows microfossil identification and analysis of the undisturbed sediment fabric including diatom mats.

\subsection{Diatom analysis}

The BSEI maps produced were used as a 'basemap' for further subsampling of the sediment fabric at millimetre scale in order to examine the link between the types of sediment fabric as observed in thin sections, and relative diatom abundance. This is necessary as cruise smear slides (Shipboard Scientific Party, 1999) and BSEI analysis of the same material show differences in their floral composition, especially egarding the relative abundance of Fragilariopsis kerguelensis. The sediment was subsampled to enable description of the full range of changes in sediment fabric observed in BSEI. Diatom slides were prepared following a method outlined in Schrader (1973). A minimum of 450 valves were identified to species level, where possible, using an Olympus BH2 optical microscope. Counts were undertaken at 1000x magnification using a 100x oil immersion objective DPlan 100PO. The counting convention outlined in Fenner (1991) was used, according to which only specimens continuity with one-half or more of the valve were counted. The pennate diatom Thalassiothrix antarctica can be very fragmented and only the valve poles can be reliably identified. The final count was therefore divided by two to give a representative valve count, following the convention used by Shemesh et al. (1989) and Fenner (1991).

Different sampling strategies were adopted for both intervals, due to the observed difference in sediment fabric. MIS 29 was sampled almost continuously over $4 \mathrm{~cm}$ in order to pick out very fine resolution floral changes, whereas in MIS $12 / 11$ the objective was to differentiate between LDOs and MDOs. In order to compare both the BSEI sediment fabric and species relative abundance as determined in this study, the following two ratios were calculated:

(1) $\mathrm{K}=\mathrm{T}$ ratio=relative abundance of Fragilariopsis kerguelensis divided by the relative abundance of $T$. antarctica; and

(2) $\mathrm{C}=\mathrm{T}$ ratio=relative abundance of all centric diatoms/relative abundance of $T$. antarctica.

The aim of the two ratios was to compare two methods of diatom ooze analysis on the same spatial scales where possible.

Preservation was assessed using a preservation index defined by Shemesh et al. (1989). Preservation is expressed as $\mathrm{K} /(\mathrm{K}+\mathrm{L})$, where $\mathrm{K}$ is the relative abundance of Fragilariopsis kerguelensis and $\mathrm{L}$, that of Thalassiosira lentiginosa. Since modern seawater diatom assemblages are never dominated by Thalassiosira lentiginosa, a preservation index $\quad<1$ is thought to represent $T$. lentiginosa enrichment in the sediments due to the selective dissolution of $F$. kerguelensis (see Shemesh et al. (1989) for full discussion). 


\section{Results}

Optical microscopy and SEM examination show a negligible lithogenic particle content. Washings using sodium hexametaphosphate were unnecessary to separate the particles, as previously observed in a study of South Atlantic diatomites by Fenner (1991). Carbonate is only seen as foraminiferal tests under the SEM.

\subsection{Microscale fabric analysis: Lamina types (MIS 29/12-11)}

Preliminary BSEI fabric analysis identified five laminae distinguished by their different fabric cross sections (Fig. 3). These are not directly indicative of the relative abundances of individual species as determined by traditional optical microscopy methods. The laminae types determined here are differentiated by their apparent diatom species abundance, packing, degree of fragmentation, and corrosion of the diatoms (Table 1).

Thalassiothrix antarctica laminae comprise a near-monospecific assemblage of the pennate diatom T. antarctica (Hasle and Semina, 1987). More than half of these laminae contain no other diatom frustules and are classed as pure, monospecific $T$. antarctica deposits. Unfortunately, it is not possible to subsample reliably only one lamina type due to their thickness (Table 1), and BSEI observations about monospecific deposits therefore cannot be confirmed using standard micropalaeontology methods.

Topographic imaging of $\mathrm{Au}$ coated samples shows that the pennate diatom frustules form entangled masses (Fig. 4a). Whole $T$. antarctica valves are rarely seen, but fragments exceeding $1 \mathrm{~mm}$ are abundant and well preserved. As a result these laminae appear highly porous and are very prominent in BSEI even at low magnification. Thalassiothrix antarctica mats dominate the LDO deposits in MIS 12/11 material. In terms of the overall thickness of the measured intervals in MIS $12 / 11$ and 29 , this lamina type represents $30 \%$ and $21 \%$, respectively.

Mixed pennate laminae (also referred to as mixed lamina Type I) comprise mainly intact Fragilariopsis kerguelensis and $T$. antarctica valves, sometimes with poorly preserved diatom mats (Fig. 4b). Although F. kerguelensis is seen in association with $T$. antarctica in MIS 12/11 sediments, it is difficult to distinguish between Thalassiothrix antarctica laminae and mixed pennate laminae in BSEI mode, due to their similar porosities and the difficulties in identifying $F$. kerguelensis from cross section. As a result, while logging MIS 12/11 material, these two laminae types were classed together.

Mixed centric/fragmented pennate laminae (Type II) are dominated by pennate fragments and the complete frustules of a mix of centric diatoms, often with the girdle bands (Fig. 4c). The species identified are Thalassiosira lentiginosa ( $T$. elliptipora in MIS 29) and Azpeitia tabularis, all evenly distributed within a matrix of fragmented Thalassiothrix antarctica and minor amounts of F. kerguelensis. These deposits have a lower porositythan mixed pennate laminae in BSEI. In MIS12/11 sediments, Type II deposits appear more homogenous and no mats are seen either in cross section or in Au-coated topographic samples (Figs. 3 and 4).

Mixed fragmented laminae (Type III) are a dense mixture of fragmented frustules of several of the common species, none of which appear to dominate. In MIS 12/11 fragmented lamina types may contain relics of laminated fabric and are possibly bioturbated or disturbed. Types II and III tend to dominate or entirely comprise the MDO intervals observed throughout the MIS 12/11 transition (Pearce et al., in prep.).

Centric diatom laminae comprise articulated and intact frustules of the centric diatoms Thalassiosira lentiginosa, Azpeitia tabularis, Thalassiosira elliptipora and Actinocyclus ingens (Fig. 4d). Such deposits are common in MIS 29, where they account for $15 \%$ of the total lamina count. In contrast, centric laminae are rare in MIS $12 / 11$, and most centric diatom-rich layers are classified as mixed pennate/centric laminae.

\subsection{Variation in lamina thickness}

Compared to MIS 29, laminae from MIS 12/11 transition have a greater thickness range (Table 1) and there is less of a variation in lamina types. The large thickness range is due to the fact that mixed lamina types II and III comprise MDO deposits where is difficult to establish a lamina cycle.

\subsection{Laminae succession}

Analysis of laminae succession in the LDO deposits of MIS 12/11 reveals the robust recurrence of a couplet of pure $T$. antarctica mats, followed by a mixed centric/fragmented pennate lamina. This couplet is representative of more than $80 \%$ of all lamina successions counted in the interval. In contrast, in MIS 29 five different lamina successions commonly occur (Fig. 5) without interruptions. Thalassiothrix antarctica laminae are observed in most lamina couplets, although these may be replaced by mixed pennate laminae. In the few occasions when a couplet comprises a succession of the same lamina type, there is a subtle but detectable increase in centric diatom abundance, and decrease of porosity toward the top (Fig. 5).

\subsection{Diatom species abundance}

The diatom assemblages observed using traditional optical microscopy are broadly similar to those described from core tops from the South 


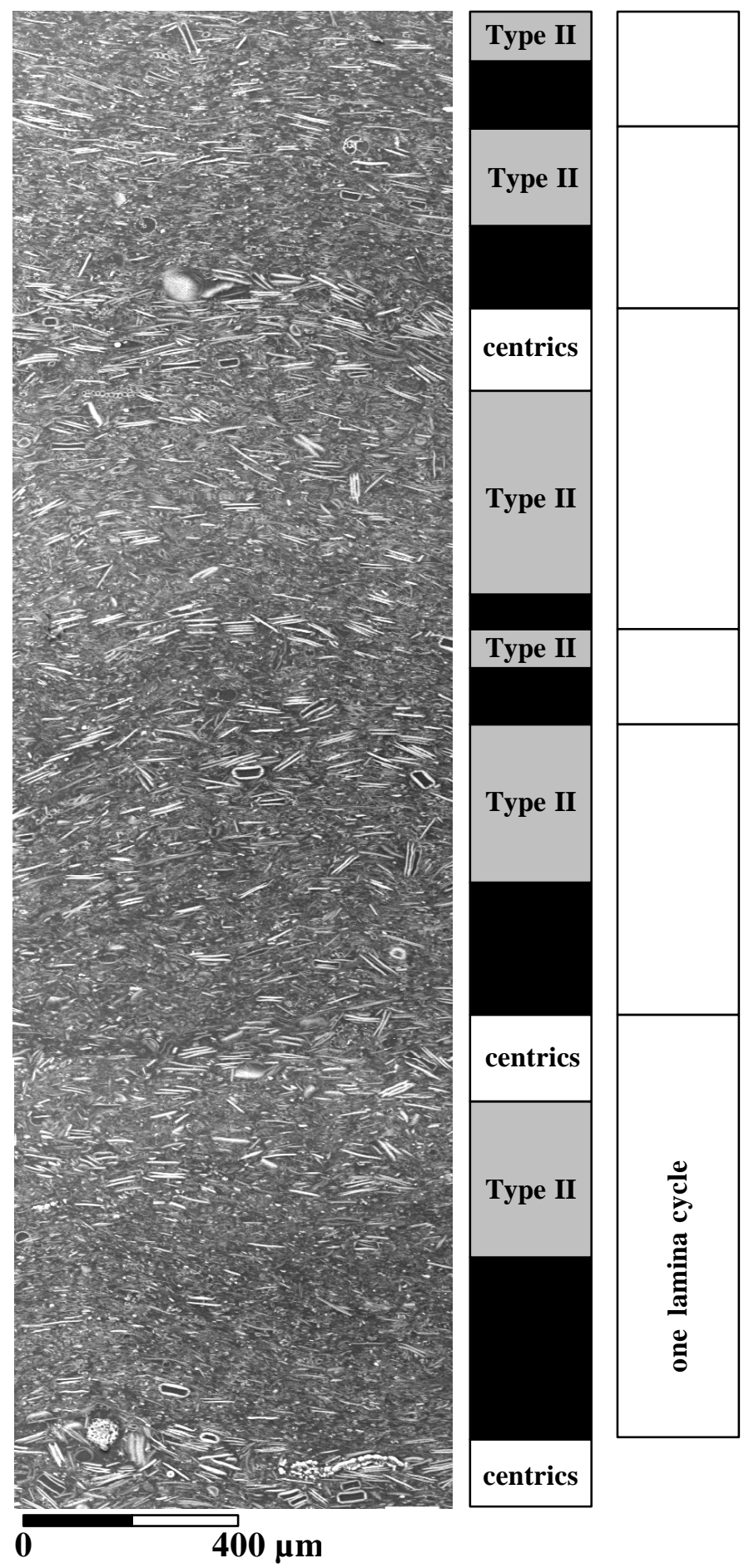

Figure 3 BSE map of fabric cross section showing the main lamina types, and the resulting lamina successions in MIS 29 (see text for discussion). 
Table 1. Lamina types and description

\begin{tabular}{|l|c|c|c|c|c|}
\hline Lamina Type & $\begin{array}{c}\text { Mean } \\
\text { thickness } \\
(\mu \mathbf{m})\end{array}$ & $\begin{array}{c}\text { Range } \\
(\mu \mathbf{m})\end{array}$ & SD & porosity & $\mathbf{n}$ \\
\hline MIS 12/11 & 347 & $60-2000$ & 319 & high & 66 \\
T. antarctica ooze +Type I & 1290 & $60-8000$ & 1836 & low & 50 \\
Type II mixed assemblage & 1646 & $100-3500$ & 1290 & low & 8 \\
Type III mixed assemblage & & & & & \\
& & & & high & 150 \\
MIS 29 & 304 & $50-1600$ & 269 & moderate & 71 \\
T. antarctica diatom ooze & 207 & $50-600$ & 119 & moderate & 197 \\
Centric diatom ooze & 531 & $70-4500$ & 461 & low & 53 \\
Type I mixed assemblage & 351 & $60-1600$ & 293 & low & 18 \\
Type II mixed assemblage & 439 & $70-1600$ & 402 & \\
Type III mixed assemblage & & & &
\end{tabular}

Atlantic (DeFelice and Wise, 1981; Zielinski and Gersonde, 1997), other than the presence of the extinct species Thalassiosira elliptipora and Actinocyclus ingens, in MIS 29 material. Downcore relative abundance and $\mathrm{K}=\mathrm{T} ; \mathrm{C}=\mathrm{T}$ ratios for both time intervals can be seen in Fig. 6. In MIS 12/11, there is no obvious relationship between the major diatom species (as determined by optical microscopy) and sediment fabric. Statistically only the relative abundance of Fragilariopsis kerguelensis and Thalassiothrix antarctica show a significant change with sediment fabric: Fragilariopsis kerguelensis is less abundant in MDO deposits (ANOVA, $\mathrm{p}=0.05 ; 95 \%$ confidence level) and Thalassiothrix antarctica is more abundant in LDO deposits (ANOVA, $\mathrm{p}=0.01 ; 99 \%$ confidence level). ANOVA tests also show that MDO deposits have significantly higher $\mathrm{C} /$ Tand $\mathrm{K} / \mathrm{T}$ ratios. The $\mathrm{C} / \mathrm{T}$ ratio incorporates species most readily observed in BSEI and hence determined sediment fabric. The fact that $\mathrm{C} / \mathrm{T}$ ratio correlates well with LDO/MDO deposits shows that BSEI $\operatorname{logs}$ of the sediment cross section are broadly representative of the diatom assemblages. This places greater confidence in the BSEI established lamina types (Figs. 3 and 4).

Changes in species relative abundance are more pronounced in the shorter MIS 29 interval, with a gradual two-fold increase in the relative abundance of $F$. kerguelensis toward the top of the subsampled interval. Although it is impossible to subsample reliably the sediment for optical diatom slides on the spatial scale of the BSEI logs $(<1000$ microns), the high sampling density used in MIS 29 shows that changes are detectable at that level and is complimentary to the sediment fabric analysis.

\subsection{Diatom preservation}

Imaging of topographic samples (BSEI mode) shows that only the fragmentation of $\mathrm{T}$. antarctica correlates with sediment fabric in MIS 12/11: well preserved, 700-1000 microns long fragments occur in the Thalassiothrix antarctica mat dominated
LDO deposits, and highly fragmented frustules in the MDO horizons. In contrast, MIS 29 contains consistently shorter $T$. antarctica fragments (200400 microns), but again there are fewer signs of dissolution and pitting in the near-monospecific mat deposits. The centric diatoms tend to be generally more fragmented, with Thalassiosira elliptipora showing most extreme cases of etching and pitting.

In order to attempt to quantify the preservation of the buried diatom assemblage in these sediments and compare it to both Recent sediment and modern sea-water assemblages, a preservation index (PI) defined by Shemesh et al. (1989) was used. The PI is based on the relative abundance of Fragilariopsis kerguelensis, which a previously mentioned does not play a role in determining sedimentary fabric from thin section analysis, and hence does not allow comparison of LDO and MDO preservation in MIS 12/11 sediments. The PI does, show however, that the well-laminated MIS 29 material contains statistically betterpreserved diatom assemblage $\left(\mathrm{PI}_{\mathrm{MIS} 29}\right.$ mean $=0.945 ;$ standard deviation $\mathrm{s}^{2}=0.04 ; \mathrm{n}=23$ ) than the intermittently laminated MIS 12/11 sediments $\left(\mathrm{PI}_{\mathrm{MIS} 12 / 11}\right.$ mean $=0.891 ; \mathrm{s}^{2}=0.035 ; \mathrm{n}=27$; ANOVA $\mathrm{PI}_{\mathrm{MIS} 29} \mathrm{vs}$. $\mathrm{PI}_{\mathrm{MIS12/11}} p=0.0001 ; 99.99 \%$ confidence level).

\section{Discussion}

\subsection{Thalassiothrix laminae}

South of the PF, in the permanently openocean zone, low light and a wind-mixed layer deeper than the euphotic zone are thought to offset the effect of high nutrient concentrations, thereby preventing blooms (Nelson and Smith, 1991; Qu!eguiner et al., 1997). To the north of the PF, vertical stability is suitable, but low silica concentrations may limit diatom productivity (Laubscher et al. 1993; Smetacek, 1998; Read et al., 2000). In the Polar frontal region, however, diatom blooms have been commonly observed (Laubscher et al.,1993; Klaas et al., 1997; Quéguiner et al., 1997). Thalassiothrix antarctica has been recorded as dominant in net phytoplankton from the PF and in the northern, warmer part of the PF (Laubscher et 

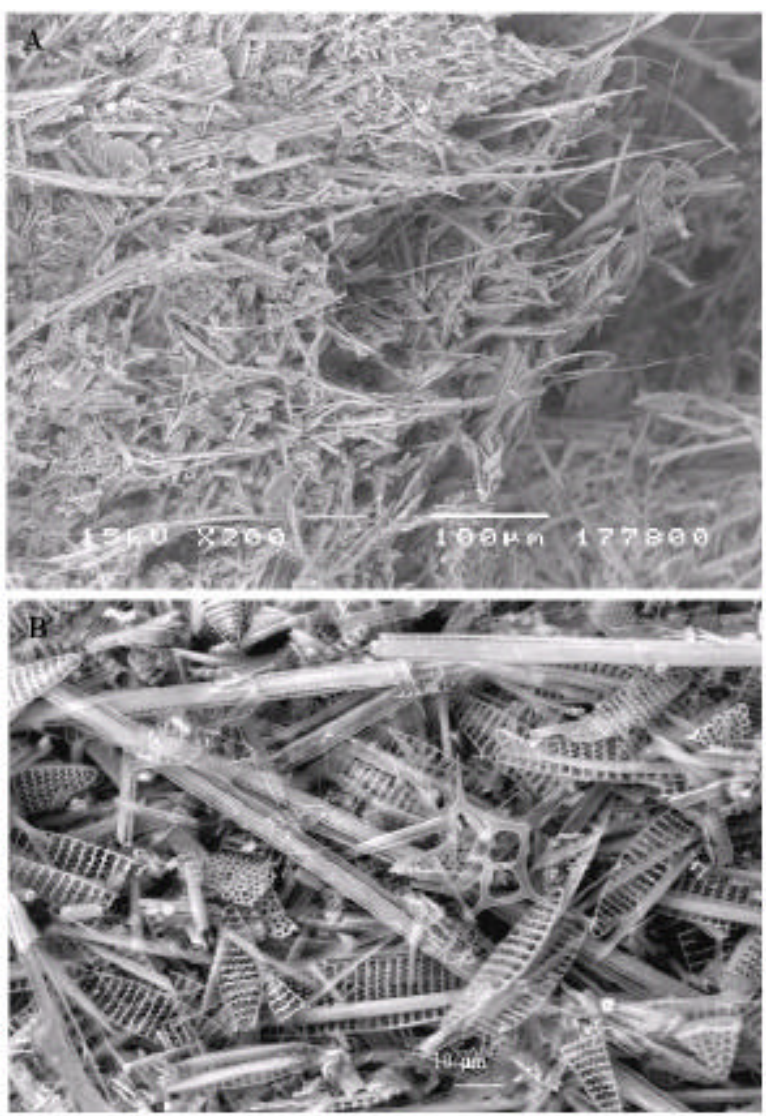
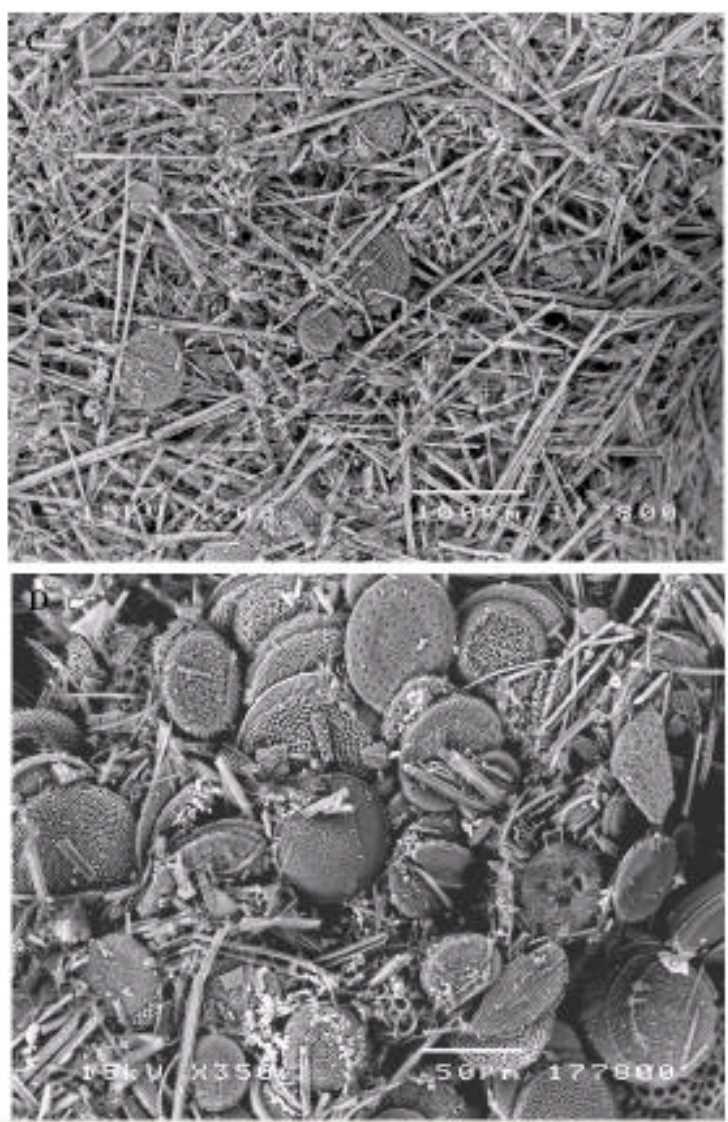

Figure 4 Topographic images (BSE mode) of untreated sediment samples, showing the depositional fabric and dominant flora in the main laminae types identified in Fig. 3: (A) T. antarctica mats. Both T. antarctica-rich deposits are shown in black on the BSE map; (B) Type I mixed assemblage of T. antarctica and F. kerguelensis; (C) Type II mixed deposits, comprising a mass of pennate fragments and centric diatoms; (D) centric diatom deposits, shown in white in Fig. 3.

\begin{tabular}{|c|c|c|c|c|c|}
\hline & & Centrics & & & \multirow{3}{*}{$\begin{array}{l}\text { Type I } \\
\text { Type I }\end{array}$} \\
\hline & Type II & Type I/II & Type II & Nm-4L & \\
\hline & T. ant & T. ant & Type I & T. ant & \\
\hline $\begin{array}{l}\text { Succession } \\
\text { Type }\end{array}$ & A & B & C & D & $\mathbf{E}$ \\
\hline $\begin{array}{l}\% \text { of total } \\
\text { successions: } \\
\text { in MIS 12/11 } \\
\text { in MIS } 29\end{array}$ & $\begin{array}{l}80.5 \\
32.8\end{array}$ & 27.5 & $\begin{array}{r}12.2 \\
20.1\end{array}$ & $\begin{array}{l}7.3 \\
7.4\end{array}$ & $\overline{12.2}$ \\
\hline
\end{tabular}

Figure 5 Lamina succession types A-E, as shown in Fig. 3. The occurrence of each succession type is expressed as a percentage of the total number of couplets/triplets identified. MIS 12/11 shows very low lamina sequence variability, with $80.5 \%$ of all successions identified as type A $(n=41)$. In contrast, three different succession types in MIS 29 amount to $80.4 \%$ of all successins counted $(n=189)$. 
al.,1993; Klaas et al., 1997; Bracher et al., 1999). This association with the PF is broadly consistent with core top studies showing that $T$. antarctica horizontal distribution coincides with the extent of the diatom ooze belt (Pichon et al., 1987; Burckle, 1984), and Zielinski and Gersonde (1997) suggested a direct link between Thalassiothrix distribution and high productivity at frontal systems. Elsewhere in the Southern Ocean, $T$. antarctica has been observed to aggregate along density discontinuities near the base of the euphotic layer, above the continental shelf edge in Prydz Bay (Quilty et al., 1985). Samples of this deep chlorophyll maximum also show that $T$. antarctica occurs in tangled masses or mats (Hallegraeff, 1986). Across the PF net tows down to $600 \mathrm{~m}$ consistently recovered abundant $T$. antarctica that appeared ungrazed and essentially pure (L. Burckle, pers. comm.). Studies of sediments of Neogene age in the eastern Equatorial Pacific (Kemp et al., 1995) and late Quaternary North Atlantic sequences (Bod!en and Backman, 1996) report Thalassiothrix spp. mat deposits very similar to those observed in this study. By analogy with modern studies of Yoder et al. (1994), physical accumulation along the frontal boundary is the main mechanism suggested for the concentration and consequent deposition of the equatorial Pacific and Atlantic Thalassiothrix mat deposits. There are very few studies on the spatial distribution of Thalassiothrix antarctica in the proximity of the PF, but there is evidence to suggest that when observed in high concentrations, $T$. antarctica in the northern part of the PF is in a healthy, growing phase (Hense et al., 1998). This may suggest that both physical accumulation and enhanced productivity at the front may be equally important contributors to the high densities of Thalassiothrix spp. observed both in net phytoplankton and the underlying sediments. Whatever the mechanism, however, the resulting export from the surface layer and deposition of such Thalassiothrix patches would account for the mats observed in the sediment, and their spatial and stratigraphic distribution may be employed as a proxy for the location of the PF.

\subsection{Centric diatom laminae}

While Thalassiosira lentiginosa is a common open-ocean species both north and south of the PF, Azpeitia tabularis is better defined as a subantarctic species (DeFelice and Wise, 1981; Pichon et al., 1987; Fryxell et al., 1986), reaching highest concentrations at temperatures between $10^{\circ} \mathrm{C}$ and $20^{\circ} \mathrm{C}$ (Zielinski and Gersonde, 1997). Due to their thickness (Table 1), pure centric diatom deposits are very difficult to subsample. Although thinsection BSEI analysis reveals a high abundance of paired valves frequently with girdle bands, topographic SEM imaging of untreated samples show signs of dissolution around the valve margins, suggesting that centric diatom assemblages may have been exposed to corrosive waters for longer time periods than the relatively wellpreserved $T$. antarctica mats. This suggests that diatom mats sink from the surface layer more efficiently than the centric diatoms. There are, however, no oceanographic data on the seasonality of blooms and the settling velocities of Thalassiosira lentiginosa or Azpeitia tabularis.

\subsection{Lamina couplets-an annual record of surface export? \\ Over the last $800 \mathrm{kyr}$, highest sedimentation} rates are found in Site 1093, declining in other Leg 177 sites away from the PF (Shipboard Scientific Party, 1999). The average sedimentation rate for the last six glacial cycles is $25 \mathrm{~cm}$ kyr-1 (Shipboard Scientific Party, 1999). During the extended sequence representing the MIS 12/11 transition, sedimentation rates are estimated at $40 \mathrm{~cm}$ kyr- 1 (Shipboard Scientific Party, 1999). The average thickness of a lamina cycle in the LDO intervals of Termination $\mathrm{V}$, is on average 570 microns $\left(\mathrm{s}^{2}=94\right.$; $\mathrm{n}=41$ ). If these lamina cycles are truly annual, this converts to $57 \mathrm{~cm} \mathrm{kyr}-1$. The aggregate thickness of the LDO intervals amounts to $1.45 \mathrm{~m}$ (R. Pearce, unpubl. data), i.e., all LDO intervals would represent $<3000 \mathrm{yr}$. The remaining $3.18 \mathrm{~m}$ of MIS $12 / 11$ transition is MDO intervals. Taking into account that Termination $\mathrm{V}$ lasted approx. $29 \mathrm{kyr}$ (Hodell et al., 2000), the average sedimentation rate for the MDO intervals must be approx. $12 \mathrm{~cm}$ kyr1. The different sedimentation rates for the LDO and MDO deposits is consistent with SEM observations of diatom valve corrosion, but independent oxygen stratigraphy is needed to verify these preliminary estimates. In MIS 29 sediments, lamina cycles are on average 808 microns (standard deviation=437; $n=189$ ), converting to exceptionally high local sedimentation rates of 70-80 cm kyr- 1 . A longer sequence of sediment now needs to be analysed, to test not only the robustness of the annual couplets, but also to compare the sediment signal with Holocene and modern studies of annual surface productivity as well as diatom mat forming and deposition. In addition, the uninterrupted sequence of lamina cycles in MIS 29 may be analysed for decadal or longer climatic cyclicities, which are known to affect high-latitude surfacewater parameters (Ware, 1995; Yuan et al., 1996; Shapiro and Huang, 1997).

\subsection{Biogenic Si burial in the sediments: $F$. kerguelensis vs. T. antarctica}

Fragilariopsis kerguelensis is regarded as the most numerous species in surface waters of the Southern Ocean (Fenner et al., 1976; Kopczynska et al., 1998), and considered to be the main opal contributor of the diatom ooze belt (Kozlova, 1964; 


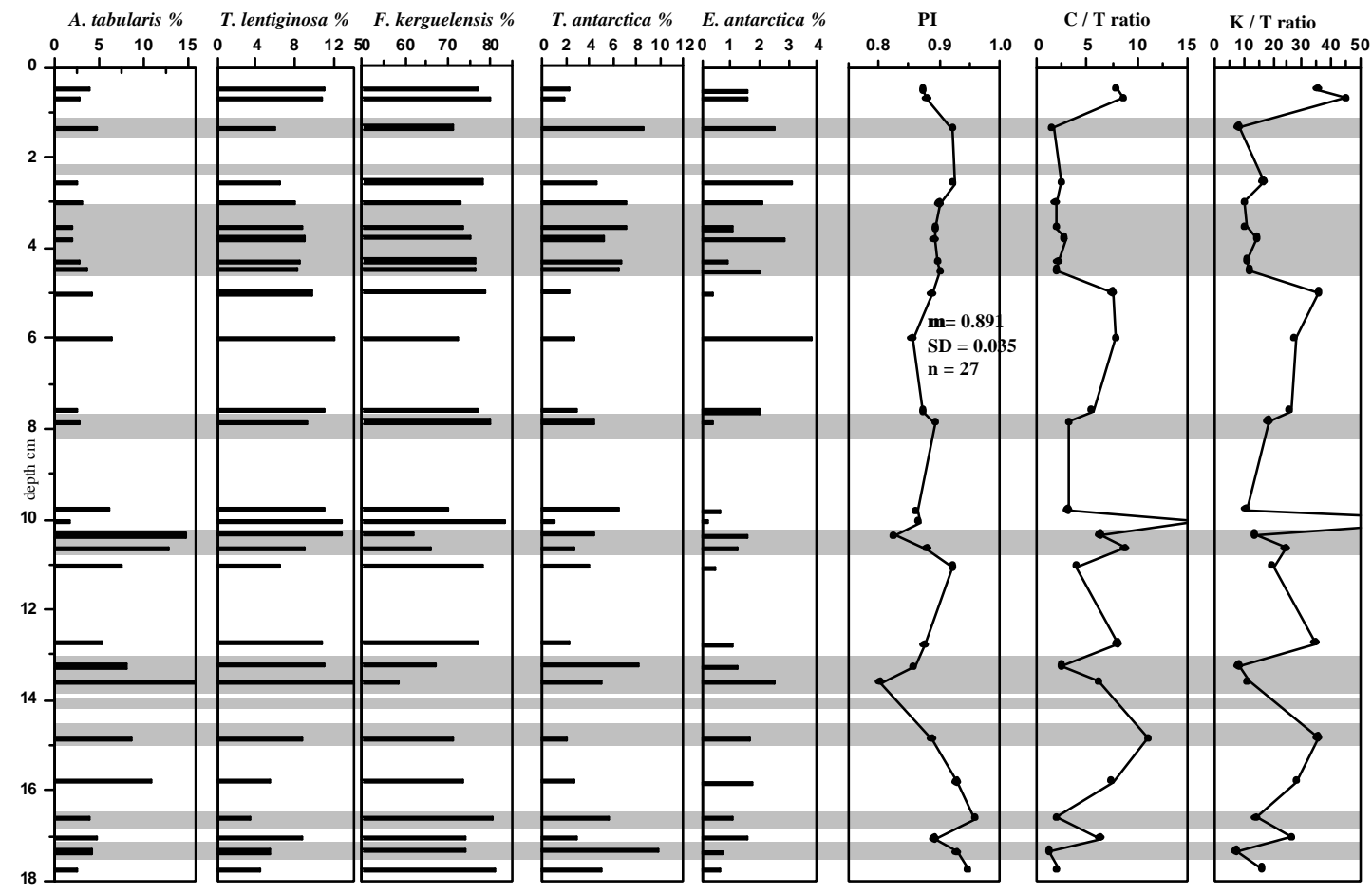

Figure 6 Down core relative abundance of major species in MIS 12/11 (a) and MIS 29 (b). A preservation index based on Thalassiosira lentiginosa enrichment (PI-Shemesh et al., 1989) is also calculated. (Note: LDOs (MIS 12/11) are indicated in grey; bar thickness is not representative of sampled interval).
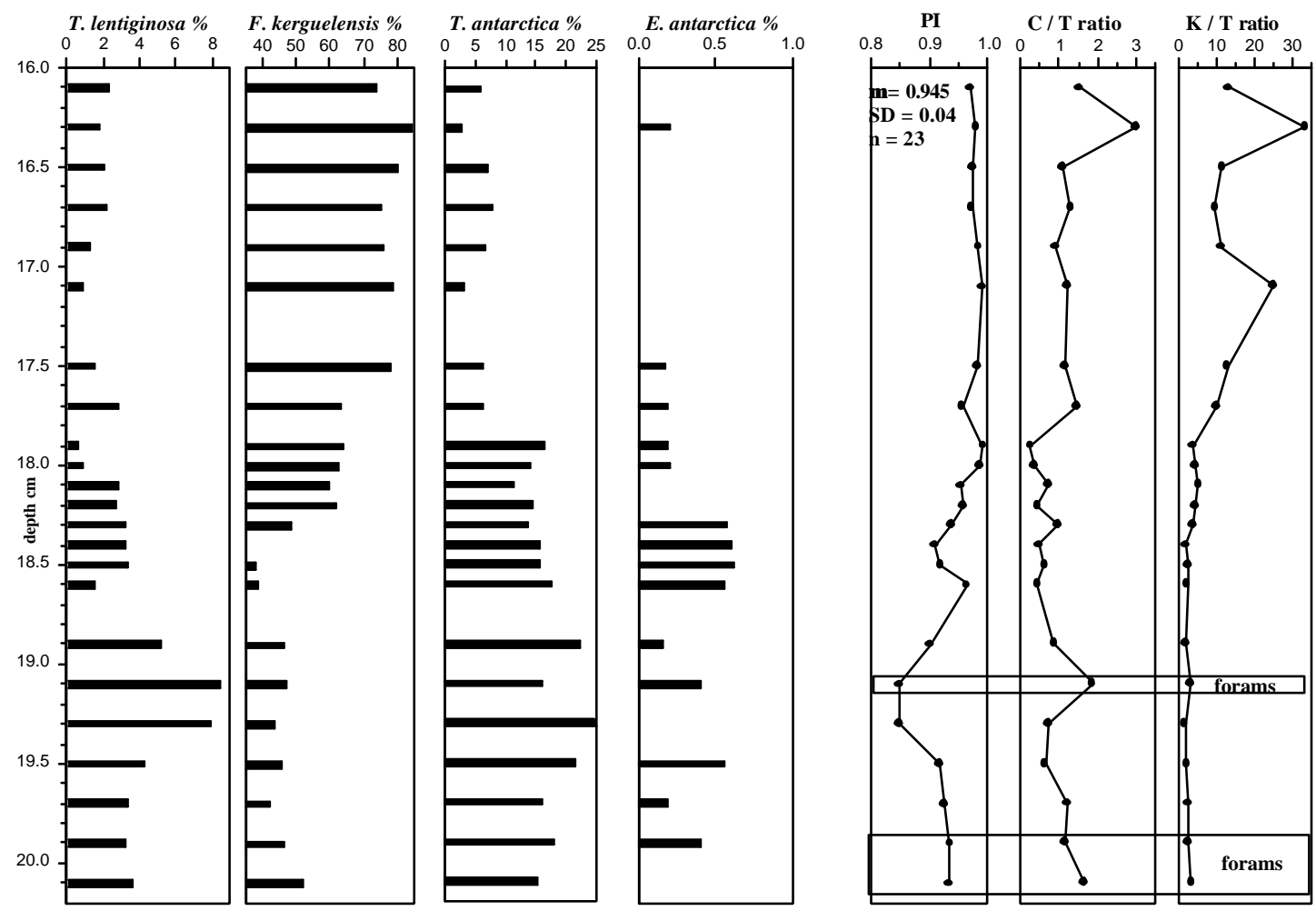
Table 2. T. antarctica and F. kerguelensis dimensions

\begin{tabular}{|c|c|c|}
\hline & $\begin{array}{c}\text { Valve } \\
\text { length } \mu \mathrm{m}\end{array}$ & Valve width $\mu \mathrm{m}$ \\
\hline T. antarctica & & \\
\hline Hallegraef 1986 & $960-5680$ & $1.5-4.7$ \\
\hline $\begin{array}{l}\text { Hasle } \\
\& \text { Semina1987 }\end{array}$ & $420-2970$ & $1.5-6$ \\
\hline Tomas, 1997 & $420-5680$ & $1.5-6$ \\
\hline Quilty, 1985 & up to 4000 & \\
\hline this study & & \\
\hline mean & & $2-6.8$ \\
\hline $\mathrm{SD}$ & & 4.22 \\
\hline $\mathrm{n}$ & & 305 \\
\hline F. kerguelensis & & \\
\hline this study & $34.6-43$ & $9.6-12$ \\
\hline mean & 38.4 & 10.1 \\
\hline $\mathrm{SD}$ & 1.9 & 0.47 \\
\hline $\mathrm{n}$ & 1200 & 1200 \\
\hline
\end{tabular}

DeFelice and Wise, 1981; Burckle and Cirrilli, 1987; Zielinski and Gersonde, 1997).

Despite being the numerically dominant species in diatom counts, it is difficult to distinguish from other pennate diatoms in thin section. In comparison, T. antarctica is less abundant in diatom counts. Despite being half as wide, $T$. antarctica valves are over 100 times longer than the average $F$. kerguelensis (Table 2). Although T. antarctica is less silicified than F. kerguelensis, $T$. antarctica mats in the sediment are interpreted as rapid fluxevents, and this elevates $T$. antarctica importance as an opal export and burial species despite its apparently low relative abundance.

\section{5. $C / T$ and $K / T$ ratios}

The $\mathrm{C} / \mathrm{T}$ and $\mathrm{K} / \mathrm{T}$ ratios were used to compare the BSEI and optical diatom count data sets. The $\mathrm{C} / \mathrm{T}$ ratio is based on the relative abundance counts of the species most readily observed in BSEI. While BSEI logging of the sediment is qualitative in terms of diatom assemblage, it is of taphonomic utility. It is not, however, representative of the presence of certain species (e.g., Fragilariopsis kerguelensis). In MIS 12/11, the strong relationship between $\mathrm{K} / \mathrm{T}$ ratio and fabric agrees with the fact that $T$. antarctica mats dominate LDO deposits, while changes of relative abundance of the diatom up-core seem complex. It would be impossible to prepare diatom slides reliably on the same spatial scale as BSEI logging, but the results of the C/T and $\mathrm{K} / \mathrm{T}$ ratios show that the two methods broadly agree and compliment each other. In addition, where possible, using the two methods on a similar spatial scale will allow for more robust definition of lamina types.

\subsection{Implications for export production}

There are no specific data on the settling rates of $T$. antarctica, but bloom diatoms are reported to sink at rates of $100-150 \mathrm{~m} \mathrm{~d}-1$ in the North Atlantic (Billet et al., 1983), and $175 \mathrm{~m} \mathrm{~d}-1$ in the North Pacific (Takahashi, 1986). These estimates are obtained in situations where transport within pellets can be ruled out and are not dependent on diatom size or morphology. Aggregation at the end of diatom blooms may explain these high settling velocities (Alldredge and Gotschalk, 1989; Engel, 2000; Smetacek, 1985). Diatom aggregates not only sink faster out of the silica-corrosive surface layer, but may also be resistant to dissolution in deep waters (Takahashi, 1986). Previous studies show that late Quaternary, as well as modern core-top samples from the Atlantic sector of the Southern Ocean, are representative of the surface assemblage and sea-surface parameters, and even more so in the vicinity of the diatom ooze belt where preservation is good (Charles et al., 1991; Pichon et al., 1987, 1992; Zielinski and Gersonde, 1997). In fact, on glacialinterglacial time scales, the very high biogenic flux in the proximity of the PF has been linked to high burial efficiencies and preservation (Schluter et al., 1998). The well-preserved fabric in the material from ODP Site 1093 also supports evidence for rapid export, but on much shorter time scales. The relatively low fragmentation points to minimal zooplankton grazing and the consequent effects of dissolution (Gersonde and Wefer, 1987). The preservation index (PI), largely dictated by productivity of the overlying waters (Shemesh et al., 1989), shows that well-laminated sediments (MIS 29) contain a better-preserved assemblage. Comparison based on PI values also shows that MIS 12/11 and 29 samples are better preserved than Holocene and Last Glacial Maximum (LGM) sediments form the Indian, Pacific and Atlantic sectors (Shemesh et al., 1989). Both intervals have mean PI values very close to that of the average PI range of modern sea-water samples, and the dissolution estimate is low, $<7 \%$ (Fig. 7).

\section{Conclusions}

1. Compared to laminated sediments from marginal marine basins, the examined intervals lack significant terrigenous input and are entirely biogenic in origin. Variations in diatom species and the degree of fragmentation seem to be the main causes of persistent submillimetre laminations.

2. The excellent preservation of $T$. antarctica suggests rapid deposition and burial of diatommats, with minimal dissolution and grazing. Compared to LGM and Holocene sediment assemblages, the 


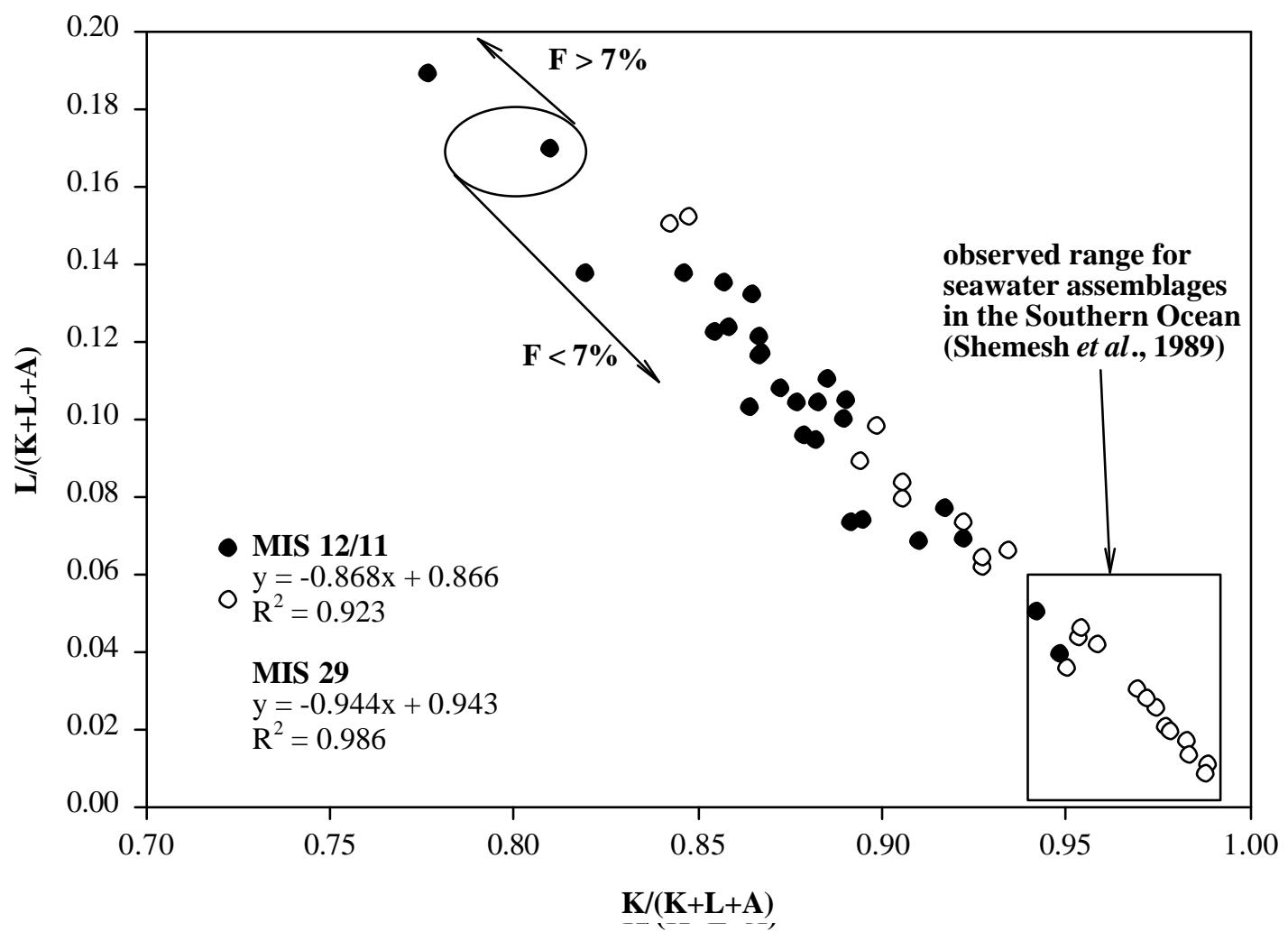

Figure 7 K-L diagram as used by Shemesh et al. (1989) to show that dissolution can be responsible for most of the variation in the thanacoenosis. The $\mathrm{K}-\mathrm{L}$ plot using results from this study, shows that MIS 29 assemblage is very similar to the average modern sea water assemblage, and that experimentally derived dissolution estimate $(\mathrm{F})$ is lowerthan $7 \%$ for both intervals.

assemblages examined in this study have a higher preservation index values.

3. Estimated bulk sedimentation for MIS 12/11 is approx. $40 \mathrm{~cm} \mathrm{kyr-1} \mathrm{(Shipboard} \mathrm{Scientific} \mathrm{Party,}$ 1999). Assuming an annual deposition of lamina couplets, the laminated diatom ooze deposits (LDO) record even higher pelagic sedimentation rates of $57 \mathrm{~cm} \mathrm{kyr}-1$. For MIS 29, the estimate is even higher at $80 \mathrm{~cm}$ kyr-1. As a result, local surface export and burial rates of both biogenic silica and organic carbon are likely to be much higher than long-term estimates for the Late Quaternary.

4. The identification of a probable annual lamination in the sediments means that long-term climatic change in the Southern Ocean, expressed in the changes of flux to the sediments, can be studied at an inter-annual through decadal temporal resolution. The good preservation of sedimentary fabric beyond 0.8 Mya also means that more light can be shed on the Southern Ocean hydrography prior to the onset of the 100-kyr glacial cycles.

\section{Acknowledgements}

The authors thank Kurt Grimm, Lloyd Burckle and an anonymous reviewer for improving the manuscript.

\section{Appendix}

Relative diatom abundance \% MIS 12/11 and 29 are shown in Tables 3 and 4.

\section{References}

Alldredge, A.L., Gotschalk, C.G., 1989. Direct observations of the mass flocculation of diatom blooms: characteristics, settling velocities and formation of diatom aggregates. DeepSea Research II 36, 156-171.

Boden, P., Backman, .J., 1996. A laminated sediment sequence from northern North Atlantic Ocean and its climatic record. Geology 24, 507-510.

Billet, D.S.M., Lampitt, R.S., Rice, A.L., Mantoura, R.F.C., 1983. Seasonal sedimentation of phytoplankton to the deepsea benthos. Nature 302, 520-522.

Bracher, A.U., Kroon, B.M.A., Lucas, M.I., 1999. Primary production, physiological state and composition of phytoplankton in the Atlantic Sector of the Southern Ocean. Marine Ecology Progress Series 190, 1-16.

Brodie, I., Kemp, A.E.S., 1994. Pelletal structures in Peruvian upwelling sediments. Journal of the Geological Society 15 (1), 141-150.

Bull, D., Kemp, A.E.S., Weedon, G.P., 2000. A 160-k.y.-old record of El Nino-Southern Oscillation in marine production and coastal runoff from Santa Barbara Vasin, California, USA. Geology 28 (11), 1007-1011.

Burckle, L.H., 1984. Diatom distribution and paleoceanographic reconstruction in the Southern Ocean-present and last glacial maximum. Marine Micropaleontology 9, 241-261.

Burckle, L.H., Cirilli, J., 1987. Origin of diatom ooze belt in the Southern Ocean: implications for late quaternary paleoceanography. Micropaleontology 33 (1), 82-86. 
Channell, J.E.T., Stoner, J.S., 2002. Plio-Pleistocene magnetic polarity stratigraphies and diagenetic magnetite dissolution at ODP Leg 177 Sites (1089, 1091, 1093 and 1094). Marine Micropaleontology, submitted for publication.

Charles, C.D., Froelich, P.N., Zibello, M.A., Mortlock, R.A., Morley, J.J., 1991. Biogenic opal in Southern Ocean sediments over the last 450000 years: Implications for surface water chemistry and circulation. Paleoceanography 6 , 697-728.

DeFelice, D.R., Wise, S.W., 1981. Surface lithofacies, biofacies and diatom diversity patterns as models for delineation of climatic change in the Southeast Atlantic Ocean. Marine Micropaleontology 6, 29-70.

El-Sayed, S.Z., 1978. Primary productivity and estimates of potential yields of the Southern Ocean. In: McWhinnie, M.A. (Ed.), Polar Research: To the Present and the Future. Westview, Boulder, CO, pp. 141-160.

Engel, A., 2000. The role of transparent exopolymer particles (TEP) in the increase in apparent particle stickiness (a) during the decline of a diatom bloom. Journal of Plankton Research 22, 483-497.

Fenner, J.M., 1991. Late Pliocene-Quaternary quantitative diatom stratigraphy in the Atlantic sector of the Southern Ocean. Proceedings of ODP Scientific Results, Vol. 114, pp. 97-122.

Fenner, J., Schrader, H.-J., Weinigk, H., 1976. Diatom phytoplankton studies in the South Pacific Ocean, composition and correlation to the Antarctic Convergence and its paleoecological significance. Initial Reports of the Deep Sea Drilling Project 35, pp. 757-814.

Fryxell, G.A., Sims, P.A., Watkins, T.P., 1986. Azpeitia (Bacillariophyceae) related genera and promorphology. Systematic Botany Monographs 13, 1-73.

Gersonde, R., Wefer, G., 1987. Sedimentation of biogenic siliceous particles in Antarctic waters from the Atlantic Sector. Marine Micropaleontology 11, 311-332.

Grimm, K.A., Lange, C.B, Gill, A.S., 1997. Self-sedimentation of phytoplankton blooms in the geologic record. Sedimentary Geology 110, 151-161.

Hasle, G.R., Semina, H.J., 1987. The marine planktonic diatoms Thalassiothrix longissima and Thalassiothrix antarctica with comments on Thalassionema spp and Synedra reinboldii. Diatom Research 2, 175-192.

Hallegraeff, G.M., 1986. Taxonomy and morphology of the marine planktonic diatoms Thalassionema and Thalassiothrix. Diatom Research 1, 57-80.

Hense, I.M., Bathmann, U.V., Hartmann, C., 1998. Spiny phytoplankton - slowing down the Carbon Pump in the Southern Ocean? EOS (Transaction of the Geophysical Union) 79, 89 .

Hodell, D.A., Venz, K., 1992. Toward a high-resolution stable isotopic record of the Southern Ocean during the PliocenePleistocene (4.8 to 0.8 MA). In: The Antarctic Paleoenvironment: A Perspective on Global Change, Antarctic Research Series 56, pp. 265-310.

Hodell, D.A., Charles, C.D., Ninnemann, U.S., 2000. Comparison of interglacial stages in the South Atlantic sector of the southern ocean for the past $450 \mathrm{kyr}$ : Implications for Marine Isotope Stage 11. Global and Planetary Change 24, 7 26.

Kanfoush, S.L., Hodell, D.A., 2002. Late Pleistocene (MIS 1-8) Ice-Rafting in the South Atlantic: ODP Leg 177, Site 1094. Palaeogeography, Palaeoclimatology, Palaeoecology, submitted for publication.

Kemp, A.E.S., Baldauf, J.G., 1993. Vast Neogene laminated diatom mat deposits from the eastem Equatorial Pacific. Nature 362, 141-144.

Kemp, A.E.S., Baldauf, J.G., Pearce, R.B., 1995. Origins and paleoceanographic significance of laminated diatom ooze from the eastern equatorial Pacific Ocean. Proceedings of the Ocean Drilling Program. Scientific Results, Vol. 138, pp. 641-645.

Kemp, A.E.S., Pike, J., Pearce, R.B., Lange, C.B., 2000. The "fall dump" — a new perspective on the role of a "shade flora' in the annual cycle of diatom production and export flux. Deep-Sea Research II 47, 2129-2154. King, S.C., Kemp,
A.E.S., Murray, J.W., 1995. Benthic foraminifera assemblages in Neogene laminated diatom ooze deposits in the east equatorial Pacific Ocean (Site 844). Proceedings of the Ocean Drilling Program, Scientific Results Leg 138, pp 665.

Klaas, C. , Kuhn, S., Menden-Deuer, S., Reynarson, T., Smetacek, V., 1997. Phytoplankton and heterotrophic protist counts. In: Bathmann, U., Lucas, M., Smetacek, V. (Eds.), The Expeditions ANTARKTIS XIII/1-2 of the Research Vessel "POLARSTERN"' in 1995/96, Ber. Polarforschung. 221.

Kleiven, H.F., Jansen, E., 2002. Rapid climate changes in the sub-polar south Atlantic Ocean during the mid-Pleistocene (1.0-0.7 Ma). Geology, submitted for publication.

Kopczynska, E., Fiala, M., Jeandel, C., 1998. Annual and interannual variability in phytoplankton at a permanent station off Kerguelen Islands, Southern Ocean. Polar Biology 20, 342-351

Kozlova, O.G., 1964. Diatoms of the Indian and Pacific sectors of the Anatrctic. Published for the NSF, Washington DC. by the Israel Pro gram for Scientific Translations, Jerusalem (1966), 191pp.Laubscher, R.K., Perissinotto, R., McQuaid, C.D., 1993. Phytoplankton production and biomass at frontal zones in the Atlantic Sector of the Southern Ocean. Polar Biology 13, 471-481.

Nelson, D.M., Smith, W.O., 1987. Spring distributions of density, nutrients and phytoplankton biomass in the iceedge zone of the Weddell Sea/Scotia Sea. J. Geophys. Res. 92, 7181-7190.

Nelson, D.M., Smith, W.O., 1991. Sverdrup revisited: critical depths, maximum chlorophyll levels, and the control of Southern Ocean productivity by the irradiance-mixing regime. Limnology and Oceanography 36, 1650-1661.

Pearce, R.B., Kemp, A.E.S., Baldauf, J.G., King, S.C., 1995. High-resolution sedimentology and micropaleontology of laminated diatomaceous sediments from the eastern equatorial Pacific Ocean. Proceedings of the Ocean Drilling Program. Scientific Results, Vol. 138, pp. 647-663.

Pichon, J.-J., Labracherie, M., Labeyrie, L., Duprat, J., 1987. Transfer functions between diatom assemblages and surface hydrology in the Southern Ocean sediments.

Palaeogeography, Palaeoclimatology, Palaeoecology 61, 7995.

Pichon, J.-J., Labeyrie, L., Bareille, G., Labracherie, M., Duprat, J., Jouzel, J., 1992. Surface water temperature changes in the high latitudes of the southern hemisphere over the last glacialinterglacial cycle. Paleoceanography 7, 289-318.

Pike, J., Kemp, A.E.S., 1996. Preparation and analysis techniques for studies of laminated sediments. In: Kemp, A.E.S. (Ed.), Palaeoclimatology and Palaeoceanography from Laminated Sediments, Special Publication, Vol. 116, Geological Society of London, pp. 37-48.

Pollard, R.T., Lucas, M.I., Read, J.F., 2002. Physical controls on biogeochemical zonation in the Southern Ocean. Deep- Sea Research II 49, 3289-3305.

Quéguiner, B., Tr!eguer, P., Peeken, I., Scharek, R., 1997. Biogeochemical dynamics and the silicon cycle in the Atlantic sector of the Southern Ocean during austral spring 1992. Deep-Sea Research II 44, 69-89.

Quilty, P., Kerry, K.R., Marchant, H.J., 1985. A seasonally recurrent patch of Antarctic planktonic diatoms. Search (ANZAAS) 16, 48.

Read, J.F., Lucas, M.I., Holley, S.E., Pollard, R.T., 2000. Phytoplankton, nutrients and hydrography in the frontal zone between the Southwest Indian subtropical gyre and the Southern Ocean. Deep-Sea Research II 47, 2341-2367.

Sakshaug, E., Holm -Hansen, O., 1984. Factors governing pelagic production. In: Holm-Hansen, O., et al. (Ed.), Marine phytoplankton and productivity. Springer, Berlin, pp. 1-18.

Schluter, M., et al., 1998. Si cycling in the sediments of the Atlantic sector of the Southern Ocean. Deep-Sea Research II 45, 1085-1109.

Schrader, H.-J., 1973. Proposal for a standardized method of cleaning diatom-bearing deep -sea and land-exposed marine sediments. Nova Hedwigia, Beiheft 45, 403-409. Shapiro, T., 
Huang, Z., 1997. A possible ENSO signal in the Ross Sea. Geophysical Research Letters 24, 3253-3256.

Shemesh, A., Burckle, L.H., Froelich, P.N., 1989. Dissolution and preservation of antarctic diatoms and the effect on sediment thanatocoenoses. Quaternary Research 31, 288-308. Shipboard Scientific Party, 1999. Leg 177 summary: Southern Ocean Palaeoceanography. In: Gersonde, R., Hodell, D.A., Blum, P., et al. (Eds.), 1999. Proceedings of the Ocean Drilling Program, Initial Reports, Vol. 177. College Station, TX (Ocean Drilling Program). pp. 1-67. doi:10.2973/odp.proc.ir.177.101.1999

Smetacek, V., 1985. Role of sinking in diatom life-history cycles: ecological, evolutionary and geological significance. Marine Biology 84, 239-251.

Smetacek, V., 1998. Diatoms and the silicate factor. Nature 391, 224-225.

Takahashi, K., 1986. Seasonal fluxes of pelagic diatoms in the subantarctic Pacific, 1982-1983. Deep-Sea Research 33, $1225-1251$.

Tomas, C.R., 1997. Identifying marine phytoplankton. Academic Press, New York, 858pp.

Ware, D.M., 1995. A century and a half of change in the climate of the NE Pacific. Fisheries Oceanography 4, 267-277.

Yoder, J.A., Ackleson, S., Barber, R.T., Flamant, P., Balch, W.A., 1994. A line in the sea. Nature 371, 689-692.

Yuan, X., Cane, M.A., Martinson, D.G., 1996. Climate variations: cycling around the South Pole. Nature 380, 673674.

Zielinski, U., Gersonde, R., 1997. Diatom distribution in Southern Ocean surface sediments (Atlantic Sector): implications for paleoenvironmental reconstructions. Palaeogeography Palaeoclimatology Palaeoecology 129, 213 250

Zielinski, U., Gersonde, R., 2002. Plio -Pleistocene diatom biostratigraphy from ODP Leg 177, Atlantic sector of the Southern Ocean. Marine Micropaleontology, submitted for publication. 


\section{Appendix A - Relative diatom abundance \% MIS 12/11}

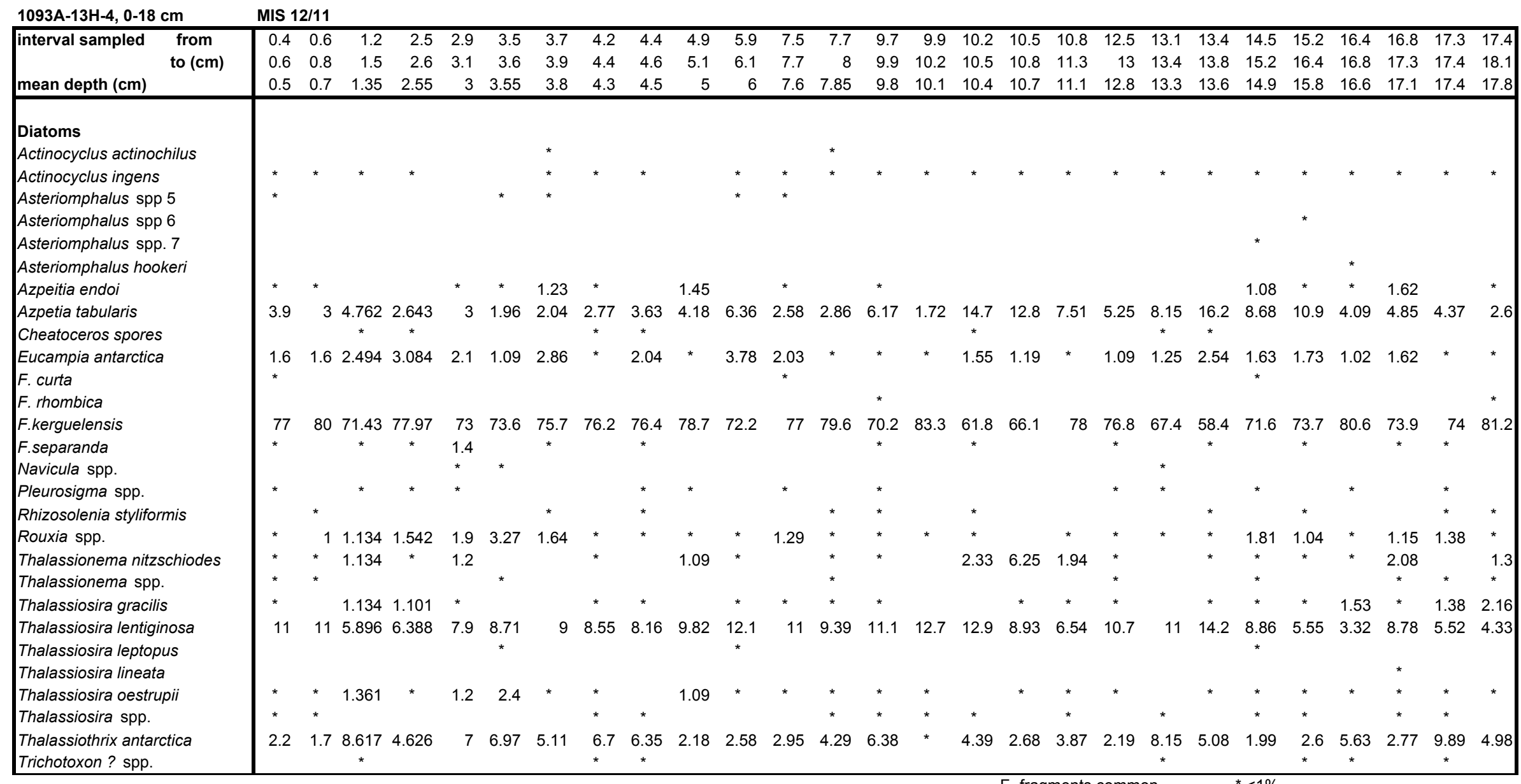

F- fragments common

${ }^{*}<1 \%$ 
Appendix B - Relative diatom abundance \% MIS 29

\begin{tabular}{|c|c|c|c|c|c|c|c|c|c|c|c|c|c|c|c|c|c|c|c|c|c|c|c|}
\hline \multirow[b]{2}{*}{$\begin{array}{l}\text { 1093A-23H-4, 0-22 cm } \\
\begin{array}{l}\text { interval sampled from } \\
\text { to }(\mathrm{cm}) \\
\text { mean depth }(\mathrm{cm}) \\
\text { slide No }\end{array}\end{array}$} & \multicolumn{23}{|l|}{ MIS 29} \\
\hline & $\begin{array}{r}16 \\
16.2 \\
16.1 \\
26\end{array}$ & $\begin{array}{r}16.2 \\
16.4 \\
16.3 \\
25\end{array}$ & $\begin{array}{r}16.4 \\
16.6 \\
16.5 \\
24\end{array}$ & $\begin{array}{r}16.6 \\
16.8 \\
16.7 \\
23\end{array}$ & $\begin{array}{r}16.8 \\
17 \\
16.9 \\
22 \\
\end{array}$ & $\begin{array}{r}17 \\
17.2 \\
17.1 \\
21\end{array}$ & $\begin{array}{r}17.4 \\
17.6 \\
17.5 \\
19\end{array}$ & $\begin{array}{r}17.6 \\
17.8 \\
17.7 \\
18\end{array}$ & $\begin{array}{r}17.8 \\
17.9 \\
17.85 \\
17\end{array}$ & $\begin{array}{r}17.9 \\
18 \\
17.95 \\
16\end{array}$ & $\begin{array}{r}18 \\
18.1 \\
18.05 \\
15\end{array}$ & $\begin{array}{r}18.1 \\
18.2 \\
18.15 \\
14\end{array}$ & $\begin{array}{r}18.2 \\
18.3 \\
18.25 \\
13\end{array}$ & $\begin{array}{r}18.3 \\
18.4 \\
18.35 \\
12\end{array}$ & $\begin{array}{r}18.4 \\
18.5 \\
18.45 \\
11\end{array}$ & $\begin{array}{r}18.5 \\
18.6 \\
18.55 \\
10\end{array}$ & $\begin{array}{r}18.8 \\
19 \\
18.9 \\
7\end{array}$ & $\begin{array}{r}19 \\
19.2 \\
19.1 \\
2\end{array}$ & $\begin{array}{r}19.2 \\
19.4 \\
19.3 \\
5\end{array}$ & $\begin{array}{r}19.4 \\
19.6 \\
19.5 \\
4\end{array}$ & $\begin{array}{r}19.6 \\
19.8 \\
19.7 \\
3\end{array}$ & $\begin{array}{r}19.8 \\
20 \\
19.9 \\
1\end{array}$ & $\begin{array}{r}20 \\
20.2 \\
20.1 \\
6\end{array}$ \\
\hline Actinocyclus actinochilus & * & & * & * & & & * & * & & & & & * & & * & & * & 2994 & 2334 & & * & * & * \\
\hline $\begin{array}{l}\text { Actinocyclus ehrenberg } \\
\text { Actinocyclus endoi }\end{array}$ & * & * & 1.068 & & 1.323 & * & * & 1.53 & * & * & * & * & 1.17 & & 1.124 & * & $\underset{*}{2.041}$ & & & 2.495 & & $\underset{*}{4.802}$ & * \\
\hline Actinocyclus ingens & 1.351 & 2.381 & 1.068 & 2.651 & * & * & * & * & * & * & * & * & 1.949 & 2.306 & 1.798 & 2.268 & 3.14 & 4.591 & 2.154 & 1.919 & 5.068 & 2.088 & 9.213 \\
\hline $\begin{array}{l}\text { Actinocyclus oculatus } \\
\text { Asteriomphalus hookeri }\end{array}$ & $*$ & & * & & & & & * & * & & & * & & & $*$ & * & & 1.198 & * & * & * & $*$ & 1.536 \\
\hline Asteriomphalus spp. A & & & & & & & & & & & & & & & & * & & & & & * & & * \\
\hline Asteriomphalus spp. B & & & & & & & & * & & & & & * & & & & & & * & * & & & * \\
\hline Azpeitia tabularis & * & * & & & * & & & * & * & & & & * & & & & & & & & & & \\
\hline $\begin{array}{l}\text { Chaetoceros spores } \\
\text { Chaetoceros veg cells }\end{array}$ & * & & & * & * & * & * & * & & & * & * & * & & & * & & * & & & & & \\
\hline $\begin{array}{l}\text { Coscinodiscus spp. } \\
\text { Eucampia antarctica }\end{array}$ & * & * & * & * & & & * & * & $\underset{*}{1.541}$ & * & & & * & * & * & * & $\underset{*}{1.256}$ & $\underset{*}{1.198}$ & * & * & $\underset{*}{2.339}$ & * & 2.495 \\
\hline F. rhombica & * & * & & * & * & * & * & * & * & * & * & * & & 1.258 & 1.124 & 1.237 & * & * & * & * & 1.559 & * & * \\
\hline F.kerguelensis & 74.32 & 85.32 & 81.32 & 75.9 & 77.5 & 83.96 & 79.72 & 67.11 & 65.51 & 63.58 & 60.35 & 63.24 & 49.71 & 33.75 & 41.12 & 43.71 & 47.41 & 45.91 & 42.01 & 47.98 & 44.05 & 48.23 & 51.82 \\
\hline $\begin{array}{l}\text { F.separanda } \\
\text { Navicula spp. }\end{array}$ & & * & & * & 1.701 & 1.679 & 0.693 & 4.971 & 2.697 & & * & * & $*$ & $\begin{array}{l}1.048 \\
1.887\end{array}$ & $\underset{*}{1.124}$ & $*$ & $*$ & $*$ & * & 1.152 & 1.949 & * & * \\
\hline $\begin{array}{l}\text { Pleurosigma spp. } \\
\text { Rhizosolenia spp. }\end{array}$ & $\mathrm{F}$ & & $\mathrm{F}$ & $\mathrm{F}$ & & & & $\mathrm{F}$ & & $\mathrm{F}$ & * & & * F & F & ${ }_{*} \mathrm{~F}$ & * & & & & & & & \\
\hline Rhizosolenia styliformis & & & * & * & * & & & & * & & * & & * & * & * & * & & & & & & & \\
\hline $\begin{array}{l}\text { Rouxia spp. } \\
\text { Thalassionema nitzchiodes }\end{array}$ & 9.459 & 3.373 & 2.847 & 4.578 & 6.427 & 6.157 & 5.026 & 10.71 & 10.02 & 15.37 & 18.57 & 14.61 & 19.69 & 36.69 & 25.84 & 23.51 & $\underset{*}{8.634}$ & 7.984 & 10.95 & 12.67 & 15.4 & 10.02 & 6.142 \\
\hline $\begin{array}{l}\text { Thalassiosira elliptipora } \\
\text { Thalassiosira gracilis }\end{array}$ & 2.124 & * & 1.957 & 2.651 & 1.701 & 1.119 & 2.426 & * & * & * & 1.547 & $\underset{*}{1.142}$ & 2.144 & * & 2.247 & 1.031 & 3.768 & 8.782 & 4.309 & 3.071 & $\underset{*}{3.899}$ & 5.219 & 4.798 \\
\hline $\begin{array}{l}\text { Thalassiosira lentiginosa } \\
\text { Thalassiosira oestrupii }\end{array}$ & 2.317 & $\underset{*}{1.786}$ & 2.135 & 2.169 & 1.323 & * & 1.56 & $\underset{*}{3.059}$ & * & * & 2.901 & $\underset{*}{2.74}$ & $\underset{*}{3.314}$ & $\underset{*}{3.354}$ & $\underset{*}{3.596}$ & 1.649 & 5.181 & $\underset{*}{8.184}$ & $\underset{*}{7.54}$ & 4.415 & $\underset{*}{3.509}$ & 3.34 & 3.647 \\
\hline Thalassiosira spp. A & & & & & & & & & & & & & * & & & * & & * & & & 1.17 & & \\
\hline Thalassiosira spp. B & & & & & & & & & & & & * & * & * & & & & & * & & * & & \\
\hline Thalassiosira spp. C & 1.158 & * & * & 1.687 & * & * & 1.386 & 1.147 & & 1.895 & 2.321 & * & 1.754 & 1.048 & 0.674 & 2.062 & 2.669 & 1.397 & 1.257 & * & 2.534 & 3.967 & 2.303 \\
\hline $\begin{array}{l}\text { Thalassiothrix antarctica } \\
\text { Trichotoxon spp. }\end{array}$ & 5.792 & 2.579 & 7.117 & 7.952 & 6.805 & 3.358 & 6.239 & 6.692 & 16.76 & 14.53 & 11.41 & 14.84 & $\underset{*}{14.04}$ & 16.14 & $\underset{*}{17.08}$ & 19.79 & 22.61 & 15.57 & 26.75 & 22.65 & 16.76 & 18.58 & 15.36 \\
\hline
\end{tabular}

